\title{
Performance Motivation and Employees of Different Generations in Slovak Industrial Enterprises
}

Ing. Augustín Stareček, PhD.

Faculty of Materials Science and Technology in Trnava

Slovak University of Technology in Bratislava

E-mail: augustin.starecek@stuba.sk

\section{Slovakia}

Ing. Kristína Koltnerová, PhD.

Faculty of Materials Science and Technology in Trnava

Slovak University of Technology in Bratislava

E-mail: kristina.koltnerova@stuba.sk

Slovakia

Ing. Natália Vraňaková, PhD.

Faculty of Materials Science and Technology in Trnava

Slovak University of Technology in Bratislava

E-mail: natalia.vranakova@stuba.sk

\section{Slovakia}

Ing. Eliška Kubišová

Faculty of Materials Science and Technology in Trnava

Slovak University of Technology in Bratislava

E-mail: eliska.kubisova@stuba.sk

$$
\text { Slovakia }
$$

Ing. Lukáš Jurík, PhD.

Faculty of Materials Science and Technology in Trnava

Slovak University of Technology in Bratislava

E-mail: 1ukas.jurik@stuba.sk

\section{Slovakia}

doc. Ing. Andrea Chlpeková, PhD.

Faculty of Materials Science and Technology in Trnava

Slovak University of Technology in Bratislava

E-mail: andrea.chlpekova@stuba.sk

Slovakia

Ing. Dominik Ďuriš

FEAG SLK Elektro s. r. o.

E-mail: dominik.duris@slkelektro.sk

Slovakia

Ing. Michaela Krchnáková

TESCO STORES a.s.

E-mail: michaela.krchnakova@tesco.com

Slovakia

\section{ABSTRACT}

Currently, there are four unique generations of employees on the labour market (Generation BB, Generation X, Generation $Y$, and Generation Z. The individual performance of employees is largely influenced by their motivation to perform. The main aim of the article is to present the results of the research focused on the analysis of the performance motivation of different generations in Slovak industrial enterprises. A standardized psychodiagnostic performance motivation questionnaire (D-M-V) was used for data collection, which was distributed to six industrial enterprises operating in Slovakia. The research sample consisted of $N=158$ respondents (administrative employees and managers). By evaluating the established research hypotheses, statistically, significant relationships were identified between the monitored variables from the D-M-V questionnaire and perceived age discrimination and the possibility of further education in industrial enterprises. Proven and quantified statistically significant relationships can be used to increase individual employee performance, which contributes to the overall performance of the organization. 


\section{Keywords: correlation analysis, D-M-V questionnaire, generations, industrial enterprises, performance motivation.}

\section{Introduction}

To effectively manage the organization, managers need to know certain personal characteristics of employees, their attitudes or opinions to delegate them appropriate tasks that correspond to their skills, abilities, and knowledge. In practice, employees with the same skills do not achieve the same performance in their tasks. This means that performance is not affected by knowledge and skills, but also by an internal degree of motivation. Employees should not only perform their tasks but also have an appetite for work and be interested in the results. Then, the manager gets into a position where it is appropriate for him to know the motivational typology of employees or the current state of motivation of his employees. The presence of different generations in one workplace makes it possible to research and define the issue from a new perspective, which will bring results that can be used in the management of production enterprises.

\subsection{Literature review}

A prosperous organization depends on the efficiency of its employees. The efficiency of employees is given by the sum of individual performance of employees and the performance of employees is to a large extent a reflection of their motivation (Tršková, 2016). Motivation can be defined as a psychological trait that influences a person in achieving the desired aim (Gribanova \& Abeltina, 2020; Hastari, et al., 2021). According to Winardi, motivation is "a potential force that an individual can develop on his own or that can be developed by many external forces, which can positively or negatively affect the results of his performance, depending on the situation and conditions facing the person concerned". (Hastari et al. 2021). Job motivation represents a willingness to make efforts to meet set aims, which are conditioned by the ability to satisfy individual needs (Singh \& Sharma, 2016; Nurdiansyah et al., 2020). Therefore, it is important in the interest of the organization to integrate employee aims with the aims of the organization. Motivation in the work process is one of the key factors that affect employee satisfaction (Heyns \& Kerr, 2018; Nurdiansyah et al., 2020). Authors Sharma \& Singh (2016) stated that job motivation is positively correlated with job satisfaction and that job satisfaction is part of the motivational process (Rahman et al., 2019). The individual with a high level of motivation can work more efficiently, with greater responsibility, and also often use their creativity compared to an individual with a low level of motivation to perform (Tršková, 2016). To increase performance, the effort to create a motivated and satisfied workforce becomes a decisive factor (Gribanova \& Abeltina, 2020).

Currently, the labor market is characterized by a great diversity of the workforce (Gyurák Babel'ová, Míkva \& Kučerová, 2021). One of the best ways to explain differences between employees is their characteristics through their affiliation to a generation (Ayub \& Rafif, 2011). The interaction of four generations (Baby boomers, Generation X, Generation Y, Generation Z) can create barriers in the labor market. There are several definitions of generations, several authors present various classifications of generations (Kutlák, 2019; Koval'ová et al., 2019, Harvinder \& Anagad, 2016; Fantini \& De Souza, 2015), which are differentiated by the year of origin of the publication, or by the geographical location of the author. For this article, we present the following classification of employees' generation, which was used in the presented research. Generation BB (1941-1960), Generation X (19611980), Generation Y (191-1995) and Generation Z (19962010).

In general, there are obvious differences between generations, such as the older generations have a calm and considered approach to work, while the younger generations are characterized by energy or self-focus. The Baby boomer's generation respects authority and hierarchy more than the younger generations, and the younger generations value the balance between work and family life more than the older generation (Jeffries \& Hunte, 2004; Abdullah et al., 2020). Older and younger generations are perceived in different ways in the job process. Research by Truxillo (2012) shows how the younger and older generations perceive each other. The older generation is perceived as conscientious, less neurotic, modest, and with higher morals. The older generation was also perceived more positively in terms of job performance and job behavior about helping the organization. Author Grandl (2016) dealt with the perception of older and younger employees. Employees from the younger generations were more satisfied with the manager within their generation due to better relationships in the workplace. On the other hand, in other managerial skills, managers of older generations were rated more positively. Older employees in all respects rated managers of older generations more positively, and it is, therefore, possible to assume that older employees prefer managers in their age category. Nevertheless, organizations still do not have enough knowledge about the motivational needs of present generations on the labor market and how they could influence the motivational strategies and performance of the organization (Jeffries \& Hunte, 2004). Understanding generational characteristics give managers a starting point that moves them to a better understanding of employees and their motivational needs (Widen et al., 2020). It is essential that the motivation system is set up effectively, and thus brings the desired results even when coordinating several generations.

\section{Material and methods}

The next part of the article contains the definition of the main aim of the article and the design of research-setting research questions and research hypotheses. The authors of the 


\section{CCenter for Promoting Education and Research (CPER) USA}

WWW.cpernet.org

paper described in the Material and methods sections the data collection tool, the method of data collection tool, the method of data collection, and the evaluation of the used methods.

\section{hypothesis}

\subsection{Research aim, research questions, and research}

The research was carried out as one of the project tasks of the VEGA project No. 1/0721/20 within the student scientific conference. The main aim of the research was to analyze the current state of motivation of employees from different generations in Slovak industrial enterprises and subsequently identify significant relationships and differences between subscales measured by the D-M-V questionnaire and further education of employees/perception of age discrimination. The results of the research will be used as a basis for creating proposals for streamlining human resources management in industrial enterprises.

\section{Research questions:}

RQ1: What is the structure of generational representation of employees in managerial and administrative positions in industrial enterprises in Slovakia?

RQ2: What score do the surveyed respondents (employees) achieve within the individual subscales of the D$\mathrm{M}-\mathrm{V}$ performance motivation questionnaire?

\section{Research hypotheses:}

RH1: There is a statistically significant relationship between the measured score in the subscale MV-performance motivation from the D-M-V questionnaire and the possibility of further education in Slovak industrial enterprises.

RH2: There is a statistically significant relationship between the measured score in the subscale $\mathrm{AB}$-anxiety inhibiting performance from the $\mathrm{D}-\mathrm{M}-\mathrm{V}$ questionnaire and the perceived age discrimination in Slovak industrial enterprises.

RH3: There are significant differences between the subscales measured by the D-M-V questionnaire for Generation $\mathrm{Z}$ and Generation $\mathrm{BB}$ in Slovak industrial enterprises.

\subsection{Data collection and data collection tool}

Data collection was carried out through the physical distribution of a research questionnaire, which was distributed to six selected Slovak industrial enterprises. In terms of the number of employees, we can classify all enterprises as medium-sized, and about the focus of production, enterprises are from the automotive industry group. 35 questionnaires were distributed to each industrial enterprise, a total of 210 questionnaires. Correctly and filled were 158 questionnaires. The return of data collection was $75.24 \%$, which can be described as a good return. Under the administration conditions, the authors of the questionnaire require absolute rest conditions, setting the average time at 20 minutes. The questionnaire was distributed to respondents in the group (Pardel, Maršálová \& Hrabovská, 1992). Respondents were selected based on the selection criteria which have been the job position of respondents. All respondents who participated in the research were administrative employees and managerial positions.

The only question focused on the identification of respondents was the age of the respondents, which will be evaluated within the RQ1. As the data collection tool, the authors of the paper used a standardized questionnaire for measuring performance motivation, which is called D-M-V (Performance motivation questionnaire). The mentioned questionnaire has three subscales: Scale MV-performance motivation, Scale AB-anxiety inhibiting performance, and Scale AP-anxiety supporting performance (Lisá, 2012). Respondents answer a total of 52 questions about three subscales, where MV consists of 24 items, AB 17 items and AP consists of 10 items. Subscales D-M-V are formed normatively, by a 6-degree Likert scale from (1) "does not apply to me at all" to (6) "completely applies to me" (Pardel, Maršálová \& Hrabovská, 1992; Bozogáňová \& Dietzovová, 214). The questionnaire contains a total of 52 items (questions), which were supplemented by three closed questions, which focused on the year of birth of the respondent, whether the respondent feels age discrimination and whether the company offers the possibility of further education.

Reliability was expressed through the coefficient of internal consistency of three subscales, the authors of the questionnaire used Cronbach's alpha to calculate the internal consistency, the values found are in the satisfactory range from $\mathrm{r}=0.81$ to $\mathrm{r}=0.87$ (Pardel, Maršálová \& Hrabovská, 1992). The authors of the article used the basic tools of descriptive statistics, which were processed using Microsoft Excel. To evaluate the research questions and research hypotheses, IBM SPSS Statistics 22 was used for further testing and using the inferential statistical tools.

\section{Results}

The next part of the article contains the statistical processing of the results from the questionnaire. The results part is divided into the evaluation of research questions and the evaluation of research hypotheses.

\subsection{Evaluation of research questions}

The evaluation of research questions was carried out based on data processing from the questionnaire using mathematical and statistical tools (figures and tables). During the processing of the first research question, it was necessary to process data from the available statistical databases, which were (Statistical Office of the Slovak Republic, 2019).

RQ1: What is the structure of generational representation of employees in managerial and administrative positions in industrial enterprises in Slovakia? The results for the sample of respondents can be seen in Table 1 below. 


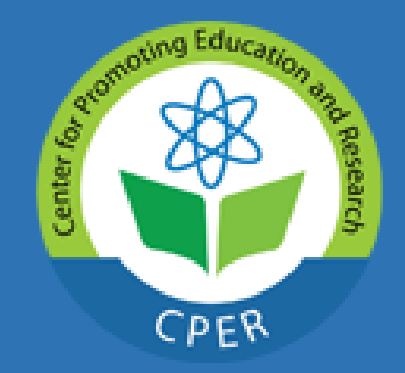

International Journal of Business and Applied Social Science (IJBASS)

E-ISSN: 2469-6501

VOL: 7, ISSUE: 4

April/2021

DOI: 10.33642/ijbass.v7n4p3

CCenter for Promoting Education and Research (CPER) USA

WWW.cpernet.org

Table 1. Composition of respondents by generation (Source: own processing, 2020)

\begin{tabular}{|l|c|c|}
\hline \multicolumn{1}{|c|}{ Generation } & Absolute frequency & Relative frequency [\%] \\
\hline Generation Z (1996-2010) & 18 & 11.39 \\
\hline Generation Y (1981-1995) & 86 & 54.43 \\
\hline Generation X (1961-1980) & 35 & 22.15 \\
\hline Generation BB (1941-1960) & 19 & 12.03 \\
\hline Total & 158 & 100.00 \\
\hline
\end{tabular}

As can be seen in Table 1, the most represented see a graphically processed number of the working population generation within-sample is Generation $\mathrm{Y}$, the least in Slovakia. These numbers are not filtered concerning the job represented group is Generation Z, which is currently position, so it can be seen what the representation of different gradually entering the labor market. In Figure 1 below, we can generations on the Slovak labor market.

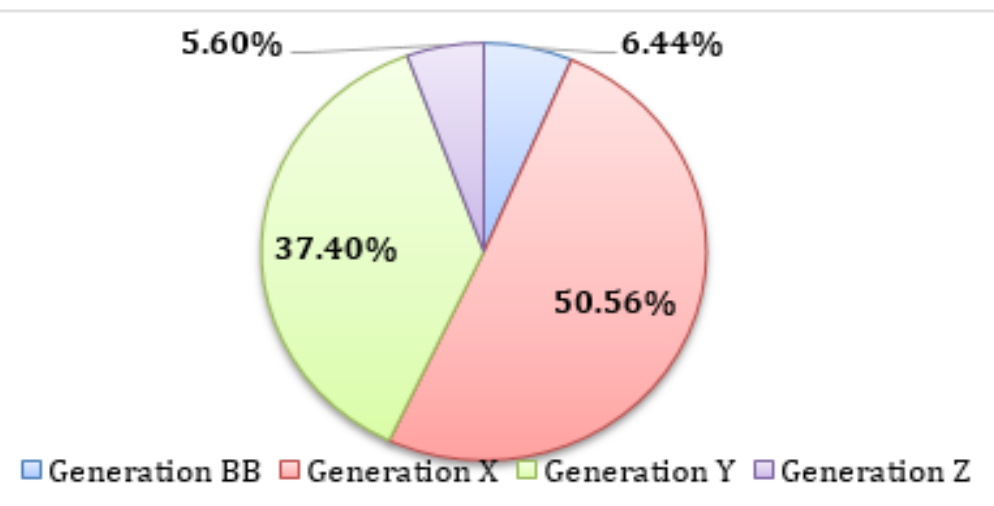

Figure 1. Generational representation of employees on the Slovak labour market (Source: own processing according to the Statistical Office of the Slovak Republic, 2020)

Figure 1 shows the representation of employees in the Slovak labor market. As we can see, the most represented employees are from Generation X, on the contrary, the least is Generation Z. Based on the comparison, we can state that even though the sample was created based on the job positions, the similarity of sample and population is high. Therefore, we can consider the layout of the sample as suitable for further research.
RQ2: What score do the surveyed respondents (employees) achieve within the individual subscales of the D$\mathrm{M}-\mathrm{V}$ performance motivation questionnaire? When evaluating the second research question, we proceeded based on the D-M$\mathrm{V}$ questionnaire. From the processing of the gross score of individual respondents and subsequent conversions to the standardized score, we created Figure 2, where we can see the data for the entire sample.

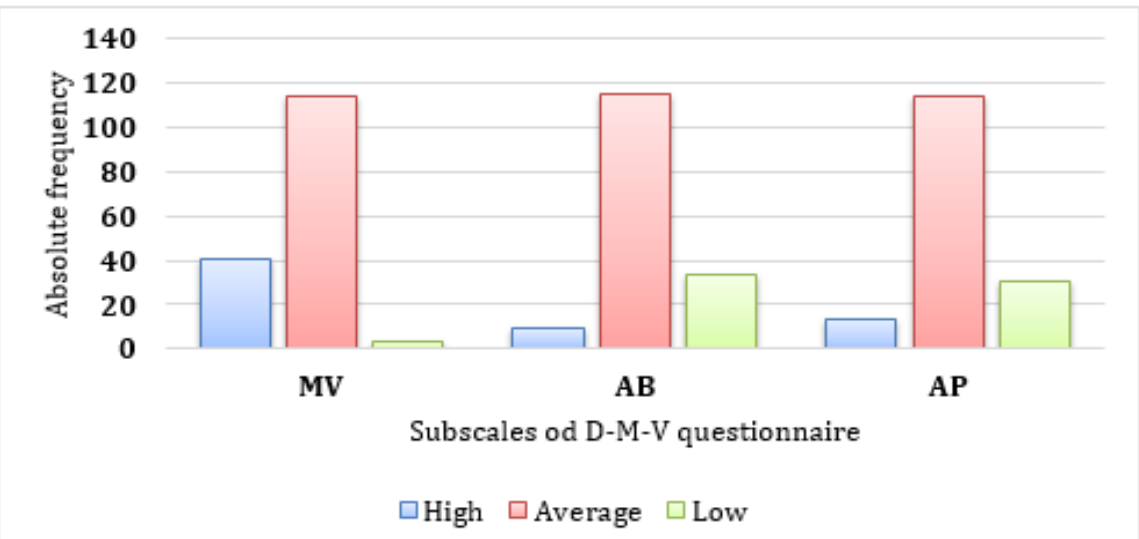

Figure 2. Results of the D-M-V questionnaire for all of respondents (Source: own processing, 2020) 
As can be seen in Figure 2, the performed analysis score and the subscale Anxiety supporting performance, 31 shows that in the subscale Motivation to performance, respondents have a low score. For a better explanation of the respondents achieve a high score (41 respondents). Anxiety results, we created Table 2 , which divides the results according inhibiting performance of up to 34 respondents achieve a low to the affiliation of respondents to individual generations.

Table 2. Evaluation of the D-M-V, divided by generations (Source: own processing, 2020
\begin{tabular}{|c|c|c|c|c|}
\hline Generation & Standardized score & Subscale MV & Subscale AB & Subscale AP \\
\hline \multirow{3}{*}{ Generation Z } & High score & 3 & 3 & 0 \\
\cline { 2 - 6 } & Average score & 15 & 13 & 12 \\
\cline { 2 - 6 } & Low score & 0 & 2 & 6 \\
\hline \multirow{3}{*}{ Generation Y } & High score & 25 & 2 & 6 \\
\cline { 2 - 6 } & Average score & 59 & 69 & 65 \\
\cline { 2 - 6 } & Low score & 2 & 15 & 15 \\
\hline \multirow{3}{*}{ Generation X } & High score & 8 & 3 & 5 \\
\cline { 2 - 6 } & Average score & 26 & 19 & 24 \\
\cline { 2 - 6 } & Low score & 1 & 13 & 6 \\
\hline & High score & 5 & 1 & 4 \\
\cline { 2 - 6 } & Average score & 14 & 4 & 2 \\
\cline { 2 - 6 } & Low score & 0 & 14 & 5 \\
\hline
\end{tabular}

From the additional analysis shown in Table 2, it can be seen that there are differences between the respondents belonging to different generations of employees. At the MV subscale, the highest score is achieved by respondents of Generation $\mathrm{Y}$ and Generation BB. At subscale AB, a low score is achieved by Generation $\mathrm{X}$ and Generation BB. The last analyzed subscale is AP, where a low score is achieved by respondents of Generation $\mathrm{Z}$ and Generation BB.

\subsection{Evaluation of the research hypotheses}

As a part of the research, three research hypotheses were established which were evaluated using IBM SPSS Statistics 22. Also, correlation tests and tests to verify differences between groups of respondents were used to evaluate the research hypotheses.

RH1: There is a statistically significant relationship between the measured score in the subscale MV-performance motivation from the D-M-V questionnaire and the possibility of further education in Slovak industrial enterprises.

The result of Pearson's correlation test proves that there is a statistically significant relationship between the measured score in the subscale MV-performance motivation and the possibility of further education in Slovak industrial enterprises. Variable correlates at the sig. $=0.05$ with Pearson correlation coefficient $r=0.326$. The value of significance reached the required level (sig.<0.05), therefore we do not reject the above hypothesis and we can confirm that there is a moderate correlation between the observed variables.
RH2: There is a statistically significant relationship between the measured score in the subscale $A B$-anxiety inhibiting performance from the D-M-V questionnaire and the perceived age discrimination in Slovak industrial enterprises.

The result of Pearson's correlation test proves that there is a statistically significant relationship between the measured score in the subscale $\mathrm{AB}$-anxiety inhibiting performance and the perceived age discrimination in Slovak industrial enterprises. Variable correlates at the sig. $=0.05$ with Pearson correlation coefficient $r=0.173$. The value of significance reached the required level (sig. $<0.05$ ), therefore we do not reject the above hypothesis and we can confirm that there is a weak correlation between the observed variables.

RH3: There are significant differences between the subscales measured by the D-M-V questionnaire for Generation $\mathrm{Z}$ and Generation BB in Slovak industrial enterprises.

All parameters have a normal data distribution. The results show a statistically significant difference between Generation BB and Generation $\mathrm{Z}$ in the subscale $\mathrm{AB}$ from the $\mathrm{D}-\mathrm{M}-\mathrm{V}$ questionnaire $(\mathrm{t}=2.057, \mathrm{sig}=0.043)$. The value of significance by the Cohen $d$ parameter is $d=0.431$, which can be considered as a low measure of the effect. For the MV subscale from the D-M-V questionnaire $(\mathrm{t}=-0.356$, sig $=$ $0.723)$ and AP subscale from the D-M-V questionnaire $(\mathrm{t}=$ 0.009 , sig $=0.993$ ) was found no significant difference between the groups. 


\section{(C) Center for Promoting Education and Research (CPER) USA}

WwW.cpernet.org

\section{Conclusion and discussion}

The performance of the company, as well as the fulfillment of company goals, depends to a large extent on the state of motivation of the employees. Based on the above, we can say that one of the leading tasks of companies is to identify and work with the motivation of employees, who are the key capital of companies (Arshed, Rauf \& Bukhari, 2021). Many types of research focus on measuring and analyzing motivation solely in terms of the arrangement of motivational factors (Ližbetinová et al., 2020; Stachová et al., 2018; Hussainy, 2020), which are easily influenced by companies.

The main aim of the research was to analyze the current state of motivation of employees from different generations in Slovak industrial enterprises and subsequently identify significant relationships and differences between subscales measured by the D-M-V questionnaire and further education of employees/perception of age discrimination. The evaluation of the research questions showed that the motivational items (subscales of the D-M-V questionnaire) are different for representatives of different generations of employees. The negative finding is that employees from Slovak industrial enterprises show low scores in anxietysupporting performance (AP subscale). The most significant is the case of Generation $\mathrm{Z}$ and Generation BB employees, whose anxiety in the job process causes reduced motivation, which results in reduced job performance or termination of employment. Both generations are important for industrial enterprises in terms of their specific knowledge and skills. For Generation BB, it is experience, process knowledge as well as the wealth of tacit knowledge (Airey, et al., 2020; Míkva, Kučerová \& Gyurák Babel'ová, 2020). Generation Z employees, on the other hand, offer their advanced digital skills, good language skills as well as high flexibility at work (Kutlák, 2019; Baldonado, 2018). The authors of the paper consider as positive the fact that the respondents from Generation $\mathrm{X}$ and Generation BB show low scores at the subscale $\mathrm{AB}$ (anxiety inhibiting performance). The mentioned finding can be characterized as the ability to manage anxiety, which results in performance. Many studies have shown that the employees from Generation X and Generation BB can handle crisis and problem situation (Míkva, Kučerová \& Gyurák Babel'ová, 2020).

The evaluation of RH1 showed that employees who achieve high scores of performance motivation (MV subscale) are interested in further education. This fact is important for planning employee development. Employees who are interested in further development are more motivated and this fact has a significant impact on their job performance. The RH3 showed that the anxiety inhibiting performance (subscale $\mathrm{AB}$ ) and oppression that causes failures in job performance is different for Generation $\mathrm{Z}$ and Generation BB. As mentioned above, the representatives of Generation BB are better placed to handle a crisis or problematic job situation. Generation $\mathrm{Z}$ does not have enough job experience and therefore it is important to approach it with more emphasis. Several studies have shown that Generation $\mathrm{Z}$ representatives have high turnover than employees of other generations (Čambál, et al., 2018; Septiavan \& Masurink, 2020; Boyer et al., 2020). Based on the above, we can recommend to industrial enterprises to place more emphasis on the incorporation of new employees from Generation Z. It is also important to involve the adaptation process in all its elements (social adaptation, adaptation to corporate culture as well as job adaptation).

The authors of the paper plan in the future to expand the sample by more respondents as well as by respondents who will also work at manufacturing job positions. Further research will focus on employee motivation related to alternative work regimes such as home office and the like.

\section{Acknowledgment}

The paper is a part of project VEGA No. 1/0721/20 "Identification of priorities for sustainable human resources management for disadvantaged employees in the context of Industry $4.0^{\prime \prime}$.

\section{References}

Abdullah, M., Alferjany, O. A. \& Alias, R. B. (2020). Generational Differences in values and attitudes within workplace. Psychology and Education, 57(9), 1496-1503. https://doi.org/10.17762/pae.v57i9.489.

Airey, L., Lain D, Jandrić, J. \& Loretto, W. (2020). A selfish generation? Baby boomers, values, and the provision of childcare for grandchildren. The Sociological Review. https://doi.org/10.1177/0038026120916104.

Arshed, N., Rauf, R. \& Bukhari, S. (2021). Empirical Contribution of Human Capital in Entrepreneurship. Global Business Review. https://doi.org/10.1177/0972150920976702.

Ayub, N. \& Rafif, S. (2011). The Relationship between Work Motivation and Job Satisfaction. Pakistan Business Review, 13(2), 332-347.

Baldonado, A. M. (2018). Leadership and Gen Z: Motivating Gen Z Workers and Their Impact to the Future. International Journal of Managerial Studies and Research, 6(1), 56-60. http://dx.doi.org/10.20431/2349-0349.0601008. 
Boyer, S., Fleming, D. E., Rodriguez, M. \& Cohen, Scott, R. (2020). Empirical Investigations of the Impact of Entrepreneurial Orientation and Grit on Salesperson Turnover for Generation Z. Journal of Managerial Issues, 32(2), 144-161.

Bozogáňová, M. \& Dietzová, S. (2014). Výkonová motivácia u hráčov online rolových počítačových hier / Performance Motivation of Players of Massively Multiplayer Online Role-playing Games. Človek a spoločnost' - Individual and Society, 17(3), 35 - 46.

Čambál, M., Urbanovičová, P., Mikulášková, J., \& Szabó, P. (2017). Koexistencia rôznych generácií zamestnancov - výzva pre súčasné priemyselné podniky. Fórum manažéra, (2), 8-14.[Online].[Accessed:13-12-2020]Retrieved from https://forummanazera.sk/cms/art_db/2017-2-2.pdf

Fantini, C. \& Souza, N. (2015). Análise dos fatores motivacionais das gerações baby boomers, X, Y e Z e as suas expectativas sobre carreira profissional. Revista iPecege, 1(3/4), 126-145. https://doi.org/10.22167/r.ipecege.2015.3-4.126.

Grandl, S. A. (2016). Differences in the Perception of Young Compared to Old Managers. Lisabon: Universitas Catolica Lisabon Business and Economics, 53. [Online]. [Accessed: 16-03-2020] Retrieved from: https://repositorio.ucp.pt/bitstream/10400.14/22758/1/152115023\%20Stefan\%20Grand1\%20W\%20NEW\%20PDFA.pdf

Gribanova, S. \& Abeltina, A. (2020). Motivation to Work and Management of it Professionals: Case of Latvia. Acta Prosperitatis, 11, 57-71. https://doi.org/10.37804/1691-6077-2020-11-57-71.

Gyurák Babel’ová, Z., Míkva, M. \& Kučerová, M. (2021). The leadership style, relationship with superior and intention to retain in employment. IJBASS, 7(3), 23-36. https://doi.org/10.33642/ijbass.v7n3p4.

Harvinder, S. \& Ashish, A. (2016). Understanding Generation Gap at Workplace. IOSR Journal of Business and Management, 18(8), 56-58. https://doi.org/10.9790/487X-1808015658.

Hastari, S., Mufidah, E., Wahyudi, P. \& Laksmita, D. (2021). Contribution of work ability and work motivation with performance and its impact on work productivity. Management Science Letters, 11(2), 425-434. https://doi.org/10.5267/j.msl.2020.9.026.

Heyns, M. M. \& Kerr, M. D. (2018). Generational differences in workplace motivation. SA Journal of Human Resource Management, 16, 1-10. https://doi.org/10.4102/sajhrm.v16i0.967.

Hussainy, S. S. (2020). Review on Motivational Theories \& Models: Its application for Employees Retention in Organizations. International Journal of Business and Applied Social Science, 6(1), 40-46, https://doi.org/10.33642/ijbass.v6n1p5.

Jeffries, F. L. \& Hunte, T. L. (2004). Generations and Motivation: A Connection Worth Making. Journal of Behavioral and Applied Management, 6(1), 37-55. https://doi.org/10.21818/jbam.6.1.4.

Kovalova, J., Birknerová, Z., Frankovsky, M. \& Benková, E. (2019). Differences in assessing sellers' behaviour by the customers of Baby Boom, X, Y and Z generations. 7th CBU International Conference - March 2019, Prague. https://doi.org/7. 10.12955/cbup.v7.1358.

Kutlák, J. (2019). Generations Y and Z in the workplace: perception of teamwork, Acc Journal, 25(2), 65-77. https://doi.org/10.15240/tul/004/2019-2-005.

Lisá, E. (2012). Psychologické testovanie motivácie k výkonu. 12. ročník medzinárodnej konferencie: Psychológia práce a organizácia - Máj, 2012, 69-76.

Ližbetinová, L., Hitka, M., Soušek, R. \& Caha, Z. (2020). Motivational preferences within job positions are different: empirical study from the Czech transport and logistics enterprises, Economic Research-Ekonomska Istraživanja, https://doi.org/10.1080/1331677X.2020.1863831.

Míkva, M., Kučerová. M. \& Gyurák Babel’ová, Z. (2020). The Most Important Motivational Factors for Employees in Industrial Enterprises Regarding the Differences Between Various Generational Groups, Research Papers Faculty of Materials Science and Technology Slovak University of Technology, 28(46), 1-9. https://doi.org/10.2478/rput-2020-0001.

Nurdiansyah, R., Mariam, S., Ameido, M. A. \& Ramli, A. H. (2020). Work Motivation, Job Satisfaction, and Employee Performance, Business and Entrepreneurial Review, 20(2), 153-162. https://doi.org/0.25105/ber.v20i2.8006.

Pardel, T., Maršálová, 1. \& Hrabovská, A. (1992). Dotazník motivácie výkonu. Psychodiagnostika, Bratislava.

Rahman, H., Fatema, R. \& Ali, H. (2019). Impact of Motivation and Job Satisfaction on Employee's Performance: An Empirical Study. Asian Journal of Economics, Business and Accounting, 10(4), 1-10.

https://doi.org/10.9734/ajeba/2019/v10i430112. 
Septiawan, B. \& Masrunik, E. (2020). Motivation of Generation Z at Work. Jurnal Studi Manajemen dan Bisnis, 7(2), 74-82, https://doi.org/10.21107/jsmb.v7i2.9044.

Singh, S.P. \& Sharma, H.K. (2016). Impact of Work Motivation on Job Satisfaction of Teachers in Professional Education. Research Journal of Social Science \& Management, 6(5), 90-96.

Stachová, K., Stacho, Z., Blštáková, J., Hlatká, M. \& Kapustina, L. (2018). Motivation of Employees for Creativity as a Form of Support to Manage Innovation Processes in Transportation-Logistics Companies. Naše more, 65(4), 180-186. https://doi.org/10.17818/NM/2018/4SI.3.

Tršková, K. (2016). Motivation, Performance and Efficiency. 6th CER - Comparative European Research Conference - October 2016, London, 12-14.

Truxillo, D., Bertolino, M. \& Fraccaroli, F. (2012). Perceptions of Older Versus Younger Workers in Terms of Big Five Facets, Proactive Personality, Cognitive Ability, and Job Performance. Journal of Applied Social Psychology, 42(11), 26072639. https://doi.org/10.1111/j.1559-1816.2012.00954.x.

Vasilová, I. (2012). Správa zo štatistického spracovania výsledkov dotazníka D-M-V. [Online]. [Accessed: 12-01-2021] Retrieved from: https://www.nucem.sk/d1/3736/Sprava_DMV_na_webNOcopy.pdf

Výsledky výberového zist’ovania pracovných síl za 1. štvrt'rok. 2019. Štatistický úrad Slovenskej republiky. [Online]. [Accessed: 02-06-2020] Retrieved from: https://slovak.statistics.sk/PortalTraffic/fileServlet?Dokument=66b4e1286985-4265-92c6-61ca607424e8.

Widen, G., Ahmad, F., Siven, T. \& Ivantsova, E. (2020). Understanding Generational Differences in Knowledge Sharing. 21th ECKM - European Conference on Knowledge Management, - December, 2020, Coventry -UK, 841-849. 